
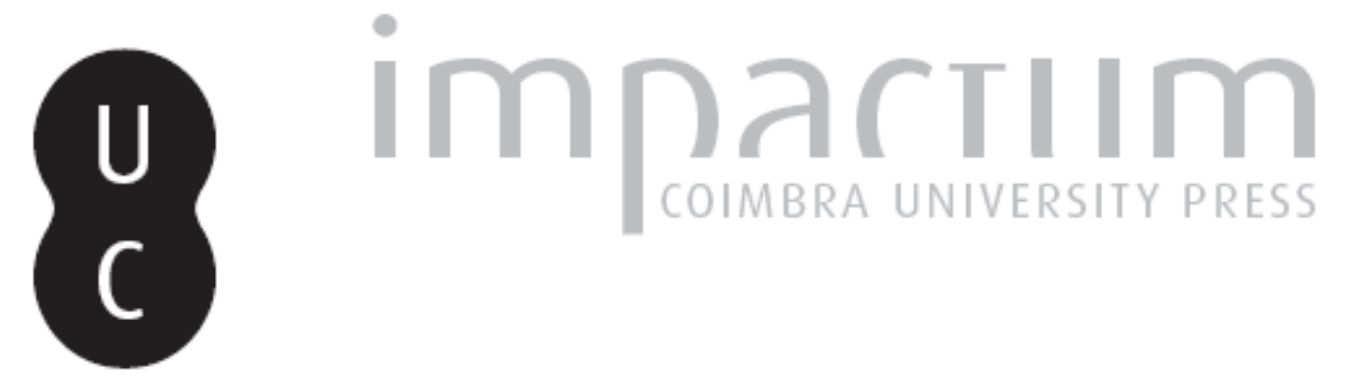

\title{
Sobre os curricula da Faculdade de Letras
}

Autor(es): $\quad$ Santos, Zulmira

Publicado por: Imprensa da Universidade de Coimbra

URL persistente:

URI:http://hdl.handle.net/10316.2/42519

DOI:

DOl:https://doi.org/10.14195/0870-8584_5_6

Accessed : $\quad$ 26-Apr-2023 07:14:10

A navegação consulta e descarregamento dos títulos inseridos nas Bibliotecas Digitais UC Digitalis, UC Pombalina e UC Impactum, pressupõem a aceitação plena e sem reservas dos Termos e Condições de Uso destas Bibliotecas Digitais, disponíveis em https://digitalis.uc.pt/pt-pt/termos.

Conforme exposto nos referidos Termos e Condições de Uso, o descarregamento de títulos de acesso restrito requer uma licença válida de autorização devendo o utilizador aceder ao(s) documento(s) a partir de um endereço de IP da instituição detentora da supramencionada licença.

Ao utilizador é apenas permitido o descarregamento para uso pessoal, pelo que o emprego do(s) título(s) descarregado(s) para outro fim, designadamente comercial, carece de autorização do respetivo autor ou editor da obra.

Na medida em que todas as obras da UC Digitalis se encontram protegidas pelo Código do Direito de Autor e Direitos Conexos e demais legislação aplicável, toda a cópia, parcial ou total, deste documento, nos casos em que é legalmente admitida, deverá conter ou fazer-se acompanhar por este aviso.

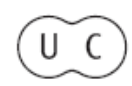




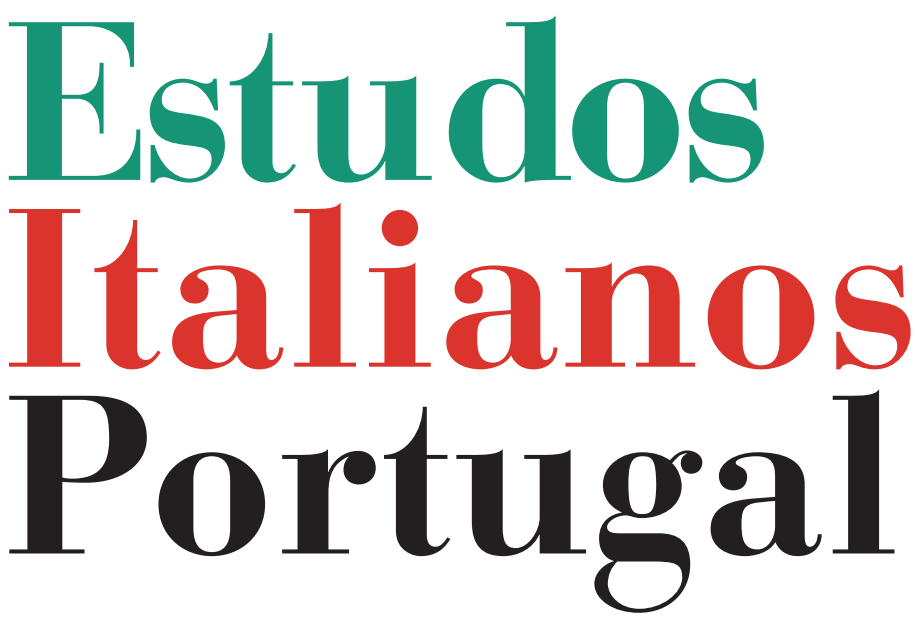

Instituto

Italiano

de Cultura

de Lisboa

Nova Série

$\mathrm{N}^{\mathbf{0}} 5$ 
SOBRE OS CURRICULA

DA FACULDADE DE LETRAS

\author{
Zulmira Santos ${ }^{\star}$
}

Trazer para o presente a memória do passado pode ajudar a desenhar o futuro. Desse ponto de vista, no momento em que as universidades portuguesas encaram um conjunto de alterações cujas consequências globais são hoje dificeis de prever, a reflexão sobre a "história" de uma língua e de uma literatura, neste caso o italiano, nos curricula da Faculdade de Letras da Universidade do Porto, pode contribuir para a avaliação da presença das literaturas e culturas europeias na formação dos nossos estudantes. De acordo com o conjunto de informações disponíveis nos Serviços de Arquivo da Faculdade de Letras da Universidade do Porto, o curso de Filologia Românica tinha no seu plano de estudos (4. ${ }^{\circ}$ ano) a disciplina de Língua e Literatura Italiana, que funcionou pela primeira vez no ano lectivo de 1972-1973, leccionada

* Professora Associada com Agregação do Departamento de Estudos Portugueses e Estudos Românicos da Faculdade de Letras da Universidade do Porto, Directora do CIUHE (Centro Interuniversitário de História da Espiritualidade), do grupo de investigação Sociabilidades, práticas e formas do sentimento religioso do Centro de Investigação Transdisciplinar Cultura, Espaço e Memória e do Curso de Doutoramento em Literaturas e Culturas Românicas da Faculdade de Letras da Universidade do Porto. Tem vindo a dedicar-se às áreas de investigação da Literatura e Cultura Portuguesas (séculos XVI-XVIII); Literatura e Cultura Espanholas (séculos XVI-XVIII); Literatura Religiosa e de Espiritualidade (séculos XVI-XVIII); História do Livro e da Leitura. 
pelo Dr. Giuseppe Mea a quem o Porto e a Faculdade de Letras muito devem na divulgação da cultura e da língua de Petrarca. No ano lectivo de 1974-1975, no quadro das modificações curriculares ocorridas após a Revolução de Abril, foram criadas duas cadeiras anuais, denominadas Língua Italiana I-II e Literatura Italiana I-II que se mantiveram até à reforma de 1978: o decreto 53/78 previa, no quadro do curso de Línguas e Literaturas Modernas, as variantes bidisciplinares com Italiano. Contudo, na FLUP nunca abriram licenciaturas que contemplassem o Italiano, tendo este funcionado apenas como opção (duas disciplinas anuais de língua e uma de literatura). A reforma de 1987, não muito diferente da anterior, previa nos planos curriculares em vigor na FLUP, duas disciplinas de Língua Italiana, a funcionar na variante de Estudos Portugueses, em alternativa com Espanhol, Francês, Inglês ou Alemão; a Literatura Italiana, em alternativa com a Espanhola, ocorria no $3 .^{\circ}$ ano da mesma variante. Em 2001, com a semestralização dos cursos, à excepção das línguas vivas, oferecem-se como opção dois níveis anuais de Língua Italiana e um nível semestral de Literatura; este cenário mantém-se, em 2004, com a criação da variante de Português - Língua, Literatura e Cultura.

A reforma de Bolonha, implementada na FLUP em 2007/2008, não modifica, no que diz respeito ao Italiano, as possibilidades de opção por parte dos estudantes: qualquer perfil de Línguas, Literaturas e Culturas, que contemple o Português, bem como o $1 .^{\circ}$ ciclo em Estudos Portugueses e Lusófonos, contam com duas unidades curriculares semestrais de Língua Italiana (Italiano A1 e A2, segundo a designação consagrada pelo Quadro Europeu de Referência) e um semestre de Literatura Italiana. Tal situação, manifestamente insuficiente, levou, aquando da revisão curricular de Novembro de 2008, à criação de um minor de Estudos Italianos (composto por 5 unidades curriculares, correspondentes a 30 ECTS) nos perfis monodisciplinares da 
licenciatura em Línguas, Literaturas e Culturas. A aposentação do Dr. Giuseppe Mea e ausência de resposta da parte do Istituto Italiano di Cultura ao pedido de financiamento de um leitor, impediram, até ao momento, a abertura deste minor. Neste momento, a língua e a cultura italiana fazem apenas parte da oferta formativa da "formação contínua", nas modalidades de "curso anual" e "cursos intensivos". A resolução deste problema, que, acreditamos, será breve, abrirá o caminho para a criação de um ramo de Estudos Italianos no Mestrado em Estudos Literários, Culturais e Interartes e de uma especialidade no Programa Doutoral em Literaturas e Culturas Românicas, criando condições para o reconhecimento da importância da língua, literatura e cultura italianas no contexto dos curricula da Faculdade de Letras da Universidade do Porto. 